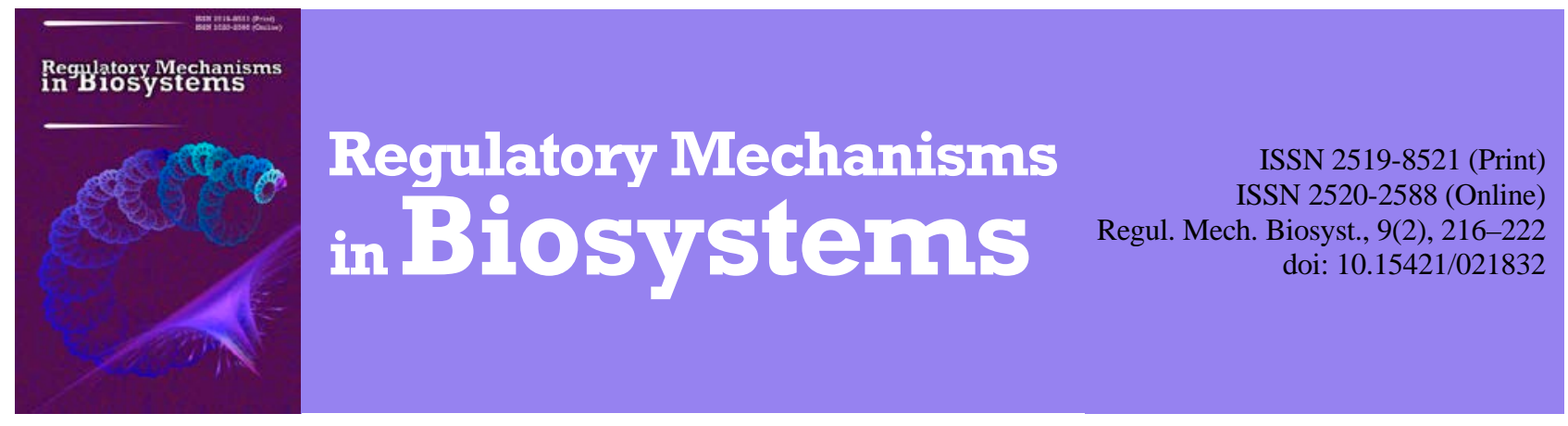

\title{
Analysis of the transmembrane potential of embryos exposed to action of nickel, cobalt, tin and zinc
}

\author{
G. V. Galyk*, Z. Y. Fedorovych*, E. I. Lychkovsky*, D. I. Sanagursky** \\ *Danylo Halytsky Lviv National Medical University, Lviv, Ukraine \\ **Ivan Franko National University of Lviv, Lviv, Ukraine
}

Article info

Received 02.03.2018

Received in revised form 07.04.2018

Accepted 10.04.2018

Danylo Halytsky Lviv National Medical University, Pekarska st., 69, Lviv, 79010, Ukraine. Tel.: +38-096-217-52-08. E-mail:

Zoryana.Ivanytska@gmail.com
Galyk, G. V., Fedorovych, Z. Y., Lychkovsky, E. I., \& Sanagursky, D. I. (2018). Analysis of the transmembrane potential of embryos exposed to action of nickel, cobalt, tin and zinc. Regulatory Mechanisms in Biosystems, 9(2), 216-222. doi:10.15421/021832

Germ cells of aquatic organisms are complex systems whose growth and development depends on many factors, one of which is the composition of the aquatic environment. We used parameters in our analysis from aggregate data available from published literature. They are data of the transmembrane potential of the germinal cells of Misgurnus fossilis (Linnaeus, 1758) at the development stage from 180th to 360th minutes. Embryos were incubated in an environment with nickel, cobalt, tin, and zinc ions and without them. Plotted lines of the transmembrane potential were digitized and calibrated at intervals of 10 minutes. Rows of numerical values of the transmembrane potentials were obtained. These rows were used for calculation of autocorrelation and cross-cross-correlation functions. It was established that the transmembrane potential describes nonperiodic and quasi-periodic oscillations. The higher statistically significant values of the autocorrelation coefficients were observed in the first lags. Autocorrelation analysis indicates that the periods of oscillations of the transmembrane potential increase with the action of nickel, cobalt, tin and zinc on the germ. The phenomena and processes that occur in the germ cell are well reflected at the initial stages of the auto-correction and are lost when the magnitude of the lag increases. The degree of similarity of transmembrane potentials with the help of cross-correlation analysis is quantitatively characterized. The distribution of fluctuations of cross-correlation functions with complex dynamics, which arise with time shifts both in the forward and reverse directions, were established. It is established that for large values of time shifts, the cross-correlation coefficient is a low-informative indicator, since information about the influence of the factor on the living system is lost. A graph for a given time shift was constructed. The connection between the nodes is the magnitude of the cross-correlation coefficients between the vapor of the transmembrane potentials, which indicate the degree of similarity of the bioelectric processes. Graphs will be used for qualitative and quantitative study of system dynamics. The obtained results confirm the existence of a close relationship between environmental nickel, cobalt, tin, and zinc and the oscillation of transmembrane potential during early embryogenesis.

\section{Аналіз трансмембранного потенціалу зародків в'юна за дії нікелю, кобальту, олова та цинку}

\author{
Г. В. Галик*, 3. Я. Федорович*, Е. І. Личковський*, Д. І. Санагурський** \\ *Львівський національний медичний університет імені Данила Галищького, Львів, Украӥна \\ **Львівський національний університет імені Івана Франка, Львів, Украӥна
}

\footnotetext{
Зародкові клітини водних організмів - складні системи, ріст і розвиток яких залежить від багатьох чинників, одним з яких є склад водного середовища. Вхідні параметри - літературні дані трансмембранного потенціалу зародкових клітин Misgurnus fossilis (Linnaeus, 1758) на стадії 180-360-ї хвилини розвитку, які інкубували в середовищі з іонами нікелю, кобальту, олова, цинку та без них. Графіки трансмембранних потенціалів переведено у цифровий формат і проквантовано з інтервалом 10 хв. Отримано ряди числових значень трансмембранних потенціалів, які у подальшому використано для обчислення автокореляційних і крос-кроскореляційних функцій. Трансмембранний потенціал описує неперіодичні та квазіперіодичні коливання. Високі статистично значущі значення коефіцієнтів автокореляції спостерігаємо у перших лагах. Автокореляційний аналіз вказує на те, що періоди коливань трансмембранного потенціалу збільшуються за дії нікелю, кобальту, олова та цинку на зародок. Процеси, які відбуваються у зародковій клітині, добре відображаються на початкових етапах автокорелограми та втрачаються у разі збільшення величини лага. Кількісно охарактеризовано ступінь подібності трансмембранних потенціалів за допомогою кроскореляційного аналізу. Встановлено поширення флуктуацій кроскореляційних функцій зі складною динамікою, які виникають за часових зсувів як у прямому, так і зворотному напрямах. За великих значень часових зсувів коефіціснт кроскореляції - малоінформативний показник,
} 
оскільки втрачається інформація про вплив фактора на живу систему. Побудовано кореляційні плеяди для заданих часових зсувів. Зв'язок між компонентами плеяд - величина коефіцієнтів кроскореляції між парами трансмембранних потенціалів, які вказують на ступінь подібності біоелектричних процесів. Кореляційні плеяди у подальшому будуть застосуватись для якісного та кількісного дослідження динаміки системи. Отримані результати підтверджують існування тісного взаємозв'язку між наявністю в середовищі інкубації зародкових клітин у ранньому ембріогенезі іонів нікелю, кобальту, олова та цинку на величину періоду коливань трансмембранного потенціалу.

Ключові слова: автокореляція; кроскореляція; зсуви; часовий ряд; важкі метали.

\section{Ветуп}

Процес саморегуляції будь-якої біологічної системи полягає у функціонуванні взаємозалежних сигнальних шляхів, які можна зобразити як позитивними, так і негативними зворотними зв'язками (Reversade \& De Robertis, 2005; Abdelalim, 2013; Huang \& Zheng, 2018). Зародкові клітини, як приклад складних систем, самореалізуються шляхом координованої динамічної експресії сотень генів та білків, у точній реакції на дію зовнішніх сигналів (температурний режим, склад середовища тощо).

Один із головних параметрів, який описує фізіологічний стан клітини, - це мембранний потенціал. Результати фізіологічних досліджень вказують на зміни в регуляції трансмембранного потенціалу, що, у свою чергу, контролюється проходженням клітини через клітинний цикл (Blackiston et al., 2009; Barghouth et al., 2015). Трансмембранний потенціал розглядають як ключовий регулятор проліферації клітин різного типу, а також припускають, що він контролює фазові переходи G1/S та G2/M (Blackiston et al., 2009). Для зародкових об'єктів у період синхронних поділів бластомерів характерні коливання біоелектричних (Goyda, 1993) та метаболічних (Abdelalim, 2013) параметрів, таких, як швидкість поглинання кисню, швидкість гліколізу, активність $\mathrm{Na}^{+}, \mathrm{K}^{+}$-АТРази, $\mathrm{Ca}^{2+}$-АТРази, казеїнкінази II. У зв'язку із цим для повного уявлення про особливості клітинних ритмів у ранньому ембріогенезі тварин проаналізовано динаміку трансмембранного потенціалу не лише за нормальних умов розвитку, а і за дії гормонів (Sanagursky \& Goyda, 1980).

Найпоширеніші забруднювачі не лише водних екосистем - іони важких металів та їх сполук, серед яких найчастіше зустрічають кобальт, нікель, залізо, цинк, мідь, кадмій (Gevorgyan et al., 2016; Blewett \& Leonard, 2017). Ці речовини токсичні, біоакумулюються (Jitar et al., 2015) та залишаються у довкіллі упродовж тривалого часу (Marzan et al., 2017). Ïx походження як природне (Neta et al., 2018), так і зумовлене діяльністю людини (Gevorgyan et al., 2016).

У водних тварин гамети виділяються у воду, де відбувається запліднення. 3 літературних даних відомо, що, залежно від концентрації, іони важких металів акумулюються у клітинах (Boiko \& Sanagursky, 2000) і впливають на гамети та ембріони, змінюючи фізіологічні властивості клітин і генерацію потенціалу дії (Boiko \& Sanagursky, 2000; Gallo, 2018).

Іони важких металів, нагромаджуючись у клітині, зумовлюють низку ефектів, як метаболічні розлади, токсичні ефекти, що спричиняють структурні зміни клітин, розвиток значних аномалій або смерть організму (Boiko \& Sanagursky, 2000; Jezierska et al., 2008; Galyk, 2017). Важкі метали впливають на амплітуду коливань трансмембранного потенціалу зародкових клітин (Boiko \& Sanagursky, 2000) - індикатор життєздатності клітини та організму в цілому.

Крива, зареєстрованого трансмембранного потенціалу на мембранах бластомерів характеризується коливальною динамікою, де період кожного коливання збігається в часі з поділом клітини у період синхронних поділів (Sanagursky \& Goyda, 1980). Тому для дослідження зареєстрованого сигналу трансмембранного потенціалу застосовують аналітичні підходи (Sanagursky \& Goyda, 1980). Розрахунок коефіцієнтів автокореляції та кроскореляції виконано у працях Sanagursky \& Goyda (1980), Ivashkiv et al. (2001) із метою встановлення тісноти зв'язку між часовими співвідношен-нями метаболічних показників (швидкість поглинання кисню, швидкість гліколізу, рівень $\mathrm{pH}$, активність казеїнкінази- $2 \mathrm{Ta} \mathrm{Na}^{+} / \mathrm{K}^{+}$АТФази) та біоелектричних показників (коефіцієнт електричного зв'язку та трансмембранний потенціал зародкової клітини). Як наслідок запропоновано критерії оцінювання динаміки показників бластомерів у період синхронних поділів за нормальних умов середовища та за дії екстремальних чинників (Sanagursky \& Goyda, 1980; Ivashkiv et al., 2001).
Вплив катіонів важких металів на зародки водних організмів актуальна проблема сучасної біології не лише з екологічної, а й із біофізичної точки зору. Порушення механізму генерування i, як наслідок, величини трансмембранного потенціалу у період синхронних поділів бластомерів - один із симптомів аномального розвитку, який може викликати зменшення чисельності водних організмів. У зв'язку з цим, мета статті - оцінити динаміку трансмембранного потенціалу зародків в'юна за дії іонів нікелю, кобальту, олова, цинку та за нормальних умов.

\section{Матеріал і методи досліджень}

Вхідні параметри - літературні дані авторів (Boiko \& Sanagursky, 2000) про зміни трансмембранного потенціалу зародкових клітин Misgurnus fossilis (Linnaeus, 1758) на 180-360-й хвилині розвитку за відсутності та наявності у середовищі інкубації іонів нікелю, кобальту, олова та цинку.

Методика обчислення кореляційної функції трансмембранного потенціалу у спрощеному вигляді полягає у такій послідовності. По-перше, зареєстровану в експерименті криву трансмембранного потенціалу необхідно подати у формі послідовності чисел, які відображають величину сигналу потенціалу для часового відрізку 180-360-та хв. Для переведення графіків у цифровий формат використали програму GetData Graph Digitizer 2.26 (Ivashkiv et al., 2001).

Наступний крок вимагав проквантувати отримані результати. Частоту вимірів обрано 10 хв. Отримано ряди числових значень трансмембранних потенціалів, які у подальшому використано для обчислення автокореляційних і крос-кроскореляційних функцій. Автокореляційний аналіз полягає у порівнянні часового ряду величин сигналу трансмембранного потенціалу із самим собою, зсунутим на деякий проміжок часу, який називається лагом. Його порівняння проводили на часовому проміжку 3 іншим часовим проміжком, який випереджує або запізнюється у часі відносно даного. 3 метою отримання «чистішої» картини періодичних залежностей (усунення впливу інших змінних) обчислюється часткова автокореляція часового ряду. Під час кроскореляційного аналізу виконують порівняння двох сигналів трансмембранного потенціалу, реєстрованих для двох клітин, у часі із запізненням і випередженням сигналу (Box et al., 2013; Huang \& Zheng, 2018).

Розрахунок автокореляційних, часткових автокореляційних i кроскореляційних функцій проводили за допомогою пакета Statistica 8.0 (StatSoft Inc., USA). Дослідження полягало у комплексному вивченні трансмембранного потенціалу, який являє собою випадковий процес, що має властивості стаціонарного. Статистичні об'єкти - часові ряди, значення в яких послідовно впорядковані в часі. Автокореляція високих порядків оцінюється за допомогою Q-тесту Льюнга - Бокса зі значенням ймовірності, з якою приймається гіпотеза про те, що автокореляція відсутня на кожному лазі за тестом Льюнга - Бокса. Достовірність кроскореляцій оцінена за таблицею граничних значень коефіцієнтів кореляції за рівня значимості $\mathrm{P}=0,05$.

\section{Результати}

Дослідження автокореляційних функцій п'яти часових рядів трансмембранних потенціалів для зародків в'юна у період раннього ембріонального розвитку, які інкубували в середовищі з іонами нікелю, кобальту, олова та цинку та без них, виявило лаги, на яких значення коефіцієнтів автокореляції виходили за межі довірчого інтервалу. Для часового ряду трансмембранного потенціалу зародків, інкубованих у середовищі без іонів важких металів на першому лазі (190-та хв) коефіцієнт автокореляції набув максималь- 
ного значення $\mathrm{r}=0,74$ на рівні значущості $\mathrm{P}=0,002$. Автокореляційний зв'язок позитивний, сильний і послідовний у лагах від першого по четвертий (період 30 хв: із 190-ї по 220-ту хв) (рис. 1a), та негативний, слабкий у лагах із 10-го по 15-й (період із 280-ї по 330-ту хв) і відсутній у лагах із 5-го по 8-й (період 30 хв: із 230-ї по 260-ту хв), оскільки значення кореляцій осцилюють близько нуля. Величини автокореляційних функцій виходять за межі довірчого інтервалу в лагах 3 першого по третій (період 20 хв: із 190-ї по 210ту хв) і з 10-го по 15-й лаг (період 50 хв: із 280-ї по 330-ту хв). Коефіцієнти автокореляції плавно змінюють знак із позитивного на негативний у шостому лазі (240 хв). Коефіцієнт часткової автокореляції виходить за межі довірчого інтервалу на першому лазі (190 хв) і набирає максимального значення 0,736 на рівні значущості $\mathrm{P}=0,0002$ (рис. 1б). Такий результат вказує на кореляцію даних, віддалених на 10 хв. Коливання пікових значень часткової автокореляційної функції відбуваються періодично з третього по одинадцятий лаги (період 80 хв: із 210-ї по 290-ту хв), за інших значень часових зсувів коливання часткової автокореляційної функції-аперіодичні.

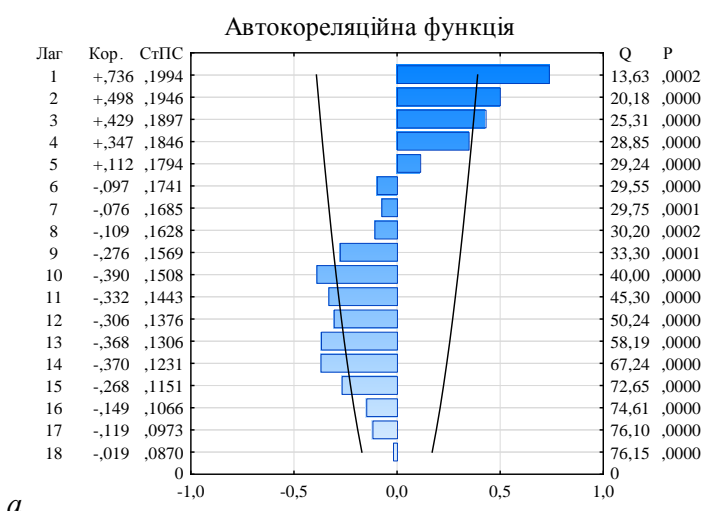

$a$

Часткова автокореляційна функція

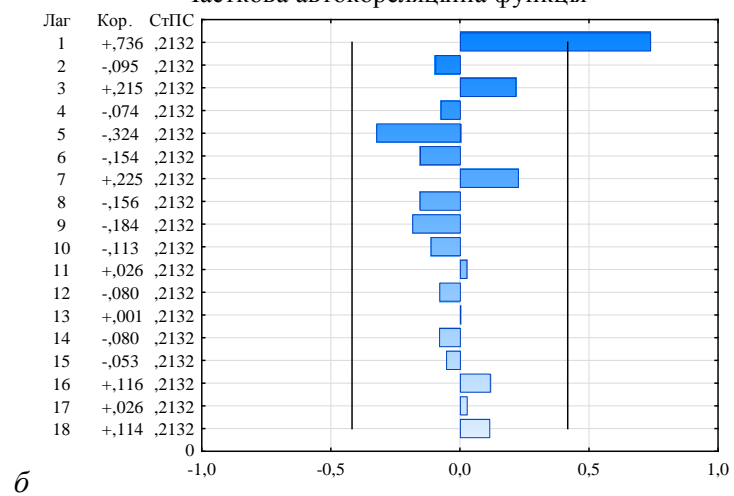

Рис. 1. Графіки автокореляційної ( $a$ ) та часткової кореляційної функції (б) для часового ряду трансмембранного потенціалу: довірчий інтервал показано чорною лінією

Для часового ряду трансмембранного потенціалу, реєстрованого на зародках в'юна, інкубованих у середовищі з нікелем, максимальне значення коефіцієнта автокореляції значуще та відповідає першому лагу (190-та хв) і становить $\mathrm{r}=0,85$ на рівні значущості $\mathrm{P}<0,001$, що вказує на сильний кореляційний зв'язок і наявність лінійного тренду (рис $2 a$ ). Автокореляційна функція позитивна достовірна в лагах із першого по третій (період 20 хв: із 190-ї по 210-ту хв) та негативна достовірна у лагах 13-18 (період 50 хв: із 310-ї по 360-ту хв). Автокореляційна функція повільно зменшується зі збільшенням лага. У зміщенні, що відповідає шостому лагу (240 хв), корелограма змінює знак на негативний, автокореляція практично відсутня $\mathrm{r}=-0,024$ за $\mathrm{P}<0,001$. Дослідження часткової автокореляційної функції виявило, що лише для першого лага значення коефіцієнта кореляції виходить за довірчий інтервал і становить 0,853 (P < 0,001). 3 першого по тринадцятий лаг (період 100 хв: із 190-ї по 310-ту хв) спостеріга- ються періодичні коливання часткової автокореляційної функції 3 періодом коливань 60 хв (рис. 2б), чого не спостерігали на графіку автокореляційної функції (рис. 2a).



Часткова автокореляційна функція



Рис. 2. Графіки автокореляційної ( $a$ ) та часткової кореляційної функції (б) для часового ряду трансмембранного потенціалу

(середовище інкубації зародків в'юна містить нікель): довірчий інтервал показано чорною лінією

Максимального значення автокореляційна функція, розрахована для часового ряду трансмебранного потенціалу, реєстрованого для зародків в'юна у середовищі інкубації з іонами кобальту, набирає у першому лазі $(190$ хв) і становить $\mathrm{r}=0,863(\mathrm{P}<0,001$, рис. $3 a$ ). Такий результат вказує на сильний кореляційний зв'язок. Автокореляційна функція для даного часового ряду характеризується повільним затуханням зі зростанням величини лага та змінює знак на від'ємний у разі зсуву, що відповідає сьомому лагу (250 хв). Автокореляція практично відсутня та коливається поблизу нуля з 7-го по 10-й лаг (період 30 хв: із 250-ї по 280-ту хв). Значення автокореляційної функції виходять за межі довірчого інтервалу з першого по четвертий (період 30 хв: зі 190-ї по 220-ту хв) і $з$ 12-го по 18-й лаг (період 60 хв: $з$ 300-ї по 360-ту хв). Часткова автокореляція у першому лазі $(190$ хв) досягає масимального значення, становить $0,863(\mathrm{P}<0,001)$ та виходить за межі довірчого інтервалу (рис. 3б). Дослідження часткової автокореляційної функції виявили періодичні коливання з 3-го по 13-й лаг (період 100 хв: із 210-ї по 310-ту хв) із періодом коливань 50 хв.

Для часового ряду величин трансмембранного потенціалу зародків в'юна, інкубованих у середовищі з оловом, автокореляційна функція характеризується затухаючими коливаннями у разі збільшення кількості лагів (рис. 4a). Автокореляційна функція змінює знак на протилежний на 7-му лазі (250 хв), величина коефіцієнта автокореляції $\mathrm{r}=0$. Максимальні значення коефіцієнтів автокореляції на першому лазі $\mathrm{r}_{1}=0,885(\mathrm{P}<0,001)$ та у другому лазі $\mathrm{r}_{2}=$ $0,738(\mathrm{P}<0,001)$ підтверджують наявність тренду. Значення коефіцієнтів автокореляційної функції виходять за межі довірчого інтервалу $з$ першого по четвертий лаг (період 30 хв: 190-220-та хв) та 3 11-го по 18-й лаг (період 70 хв: 290-360-та хв). Наявність лінійного тренду підтверджує також часткова автокореляційна функція, максимальне значення якої для першого лага становить 0,885 
( $\mathrm{P}<0,001)$ та виходить за межі довірчого інтервалу (рис. 3б).

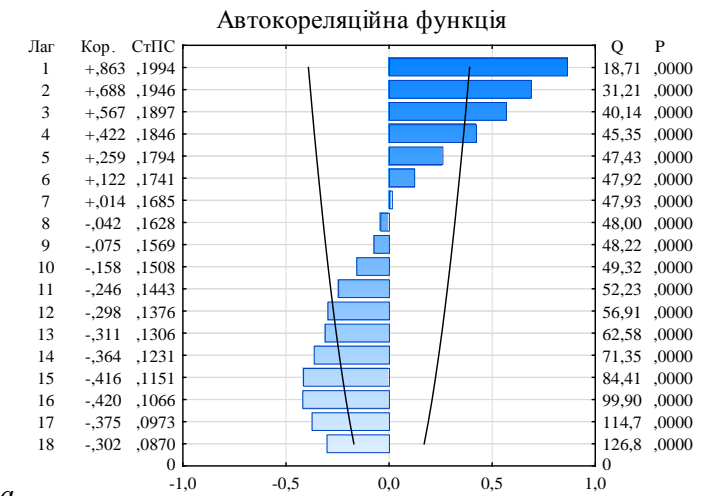

$a$

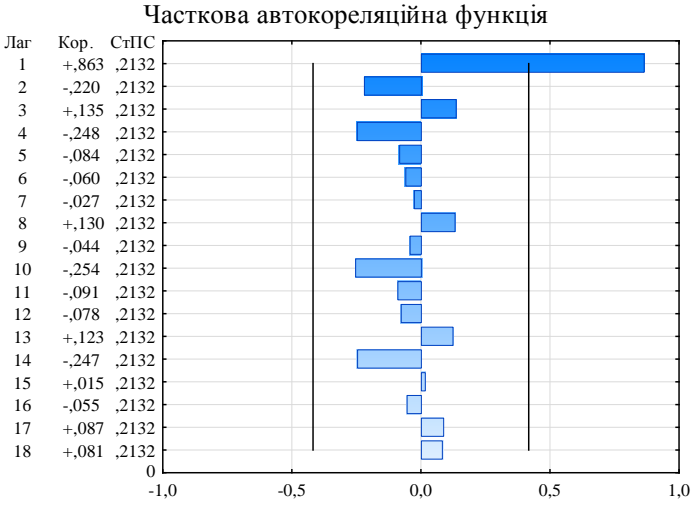

Рис. 3. Графіки автокореляційної ( $a$ ) та часткової кореляційної функції (б) для часового ряду трансмембранного потенціалу (середовище інкубації зародків в'юна містить кобальт): довірчий інтервал показано чорною лінією

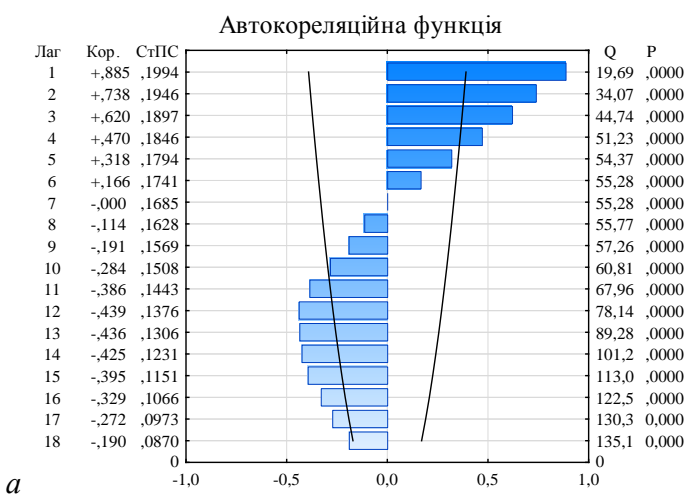

Часткова автокореляційна функція

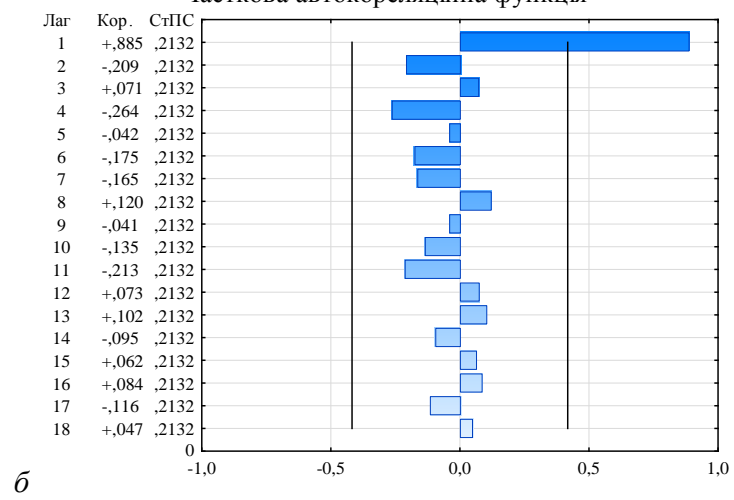

Рис. 4. Графіки автокореляційної (a) та часткової кореляційної функції (б) для часового ряду трансмембранного потенціалу (середовище інкубації зародків в'юна містить олово): довірчий інтервал показано чорною лінією

Автокрореляційна функція, обчислена для трансмембранного потенціалу зародків, інкубованих у середовищі із цинком, різко знижується зі зростанням кількості лагів, коливається близько нуля та не виходить за межі довірчого інтервалу (рис. $5 a$ ) з 2-го по 18-й лаг (період 180 хв: $з$ 200-ї по 360-ї хв). Максимальне значення коефіцієнта автокореляції відповідає першому лагу, значуще та становить $\mathrm{r}=0,611(\mathrm{P}=0,002)$, що відповідає помітній сильній щільності зв'язку. Під час зростання кількості лагів значенння коефіцієнтів автокореляції зменшуються. Коефіцієнти часткової автокореляції значущі для першого та четвертого лагів. Такі результати вказують на кореляцію даних, зміщених на 10 та 40 хв.



Рис. 5. Графіки автокореляційної ( $a$ ) та часткової кореляційної функції (б) для часового ряду трансмембранного потенціалу

(середовище інкубації зародків в'юна містить цинк): довірчий інтервал показано чорною лінією

Р-значення на всіх лагах автокореляційних функцій, окрім такої для часового ряду трансмембранного потенціалу зародків, інкубованих у середовищі із цинком, менше за рівень значимості $0,1 \%$, тому за тестом Льюнга - Бокса відхиляється гіпотеза про відсутність серійної кореляції на всіх лагах. Отже, дані досліджуваних часових рядів - не випадкові стохастичні коливання. Для всіх п'яти випадків має місце автокореляція першого порядку. Оскільки порядки автокореляції між значеннями трансмембранного потенціалу однакові, кожне наступне значення мембранного потенціалу залежить від попереднього, генерованого на 10 хв раніше. Для випадку з умістом іонів цинку у середовищі інкубації для зародкових об'єктів значення трансмембранного потенціалу залежить від попередніх, генерованих на 10 та 40 хв раніше.

Кроскореляційний аналіз десяти часових рядів сигналів, що відповідають трансмембранним потенціалам ембріональних клітин, які інкубували у різних середовищах, виявив аперіодичні коливання кроскореляційних функцій зі зміщеними відносно нульового лага (180-та хв) максимальними значеннями кроскореляцій як у прямому, так і у зворотному напрямах (рис. 6). Виходячи 3 візуального графічного аналізу, всі тимчасові ряди явно нестаціонарні. Із графіків кроскореляційних функцій видно незначні коливання коефіцієнтів кореляції, характер періодичних коливань не виражений. У цьому випадку два сигнали трансмембранного потенціалу мають велику схожість за рахунок неритмічних коливань. Наприклад, різниця в силі кореляції між трансмембранними потенціалами, виміряними для зародків, інкубованих у середовищі 
без іонів нікелю, кобальту, олова, цинку та за їх наявності, вказує на вплив іонів важких металів на загальну кореляцію сигналів. Це число може бути як позитивним, так і негативним (рис. $6 a$ ) в обох напрямах.

Взаємовплив двох сигналів - трансмембранних потенціалів, виміряних для зародкових клітин, інкубованих у середовищах без та за дії нікелю (рис. $6 a$ ), характеризується позитивною кроскореляцією, яка поширюється зі змішеннями від -1 до 12-го лага. Максимальне достовірне значення кроскореляційної функції відповідає зсуву 40 хв ( $\mathrm{r}=0,65, \mathrm{P}=0,05)$. Достовірні значення коефіцієнтів кроскореляцій реєструються за зсувів 2-7.

Крива кореляційних функцій трансмембранних потенціалів, виміряних для зародкових клітин, інкубованих у середовищах без і за дії кобальту (рис. 6a) характеризується позитивною кроскореляцією, яка виходить за межі довірчого інтервалу зі зміщеннями лага 0-6 (період 60 хв: від 180-ї до 240-ї хв). Максимальне значення коефіцієнта кроскореляції становить $\mathrm{r}=0,68$ (P = 0,05 на першому лазі). Кроскореляція трансмембранних потенціалів, виміряних для зародкових клітин, інкубованих у середовищах без і за дії олова (рис. 6a), характеризується позитивними значеннями, які відповідають зсувам від -4 до 9. Максимального значення кроскореляція набуває за зсувів на 10 хв ( $\mathrm{r}=0,77 ; \mathrm{P}=0,05)$. Значення коефіцієнтів кроскореляції виходять за межі довірчого інтервалу за зміщень у межах від -1-го до 5-го лага.

Взаємовплив трансмембранного потенціалу, виміряного на ембріональній клітині, за нормальних умов інкубації та за наявності в інкубаційному середовищі іонів цинку (рис. 6a), характеризується коливальною динамікою $з$ позитивними значеннями кроскореляційних функцій, що відповідають зміщенням у лагах -17-15 та -1-12. Максимальне достовірне значення коефіцієнта кроскореляції становить $\mathrm{r}=0,42$ на ріні значущості $\mathrm{P}=0,05$ за зсуву на 30 хв (лаг 3). Значення кроскореляційної функції не виходять за межі довірчого інтервалу.

Під час дослідження взаємовпливу сигналів трансмембранних потенціалів, зареєстрованих за інкубації ембріонів у середовищах iз нікелем і кобальтом, кроскореляційні функції характеризуються позитивними значеннями в межах часових зсувів, що відповідають лагам від -9-го до 5-го (рис. 6б). Максимальне позитивне значення коефіцієнта кроскореляції відповідає нульовому лагу та становить $\mathrm{r}=0,88(\mathrm{P}=0,05)$. Значення кроскореляційних функцій виходять за межі довірчого інтервалу при зсувавах від -4-го до 2-го.

Кроскореляційна функція взаємовпливу сигналів трансмембранних потенціалів, зареєстрованих за інкубації ембріонів у середовищах із нікелем і оловом, характеризується коливною динамікою. Значення коефіцієнтів кроскореляції виходять за межі довірчого інтервалу, що відповідають лагам від -9-го до 4-го (рис. 6б). Максимального позитивного значення кроскореляція набуває у разі зміщення у 30 хв назад (лаг -3) та становить $\mathrm{r}=0,84 ; \mathrm{P}=0,05$. Достовірні значення кроскореляційних функцій перебувають у межах зміщень від -6-го по 1-й лаг.

Аналіз взаємовпливу сигналів трансмембранних потенціалів, зареєстрованих за інкубації ембріонів у середовищах із нікелем і цинком, характеризуються коливальною динамікою з позитивними значеннями в межах часових зсувів, що відповідають лагам із -4 до 5-го (рис. 6б). Максимального позитивного значення коефіцієнт кроскореляції набирає за зсуву 10 хв назад (лаг -1) і дорівнює 0,73 (P = 0,05). Кроскореляційна функція не виходить за межі довірчого інтервалу за зсувів від -2 до 1-го.

Співставлення сигналів, зареєстрованих для ембріональних клітин, інкубованих у середовищах із кобальтом і оловом показало, що кроскореляційна функція набирає позитивних значень у межах від -8 до 6-го лага (рис. 6в). Графік кроскореляційної функції характеризується коливаннями з максимальною амплітудою в нульовому лазі, яка становить $0,87(\mathrm{P}=0,05)$. Достовірні значення кроскореляційної функції не виходять за межі довірчого інтервалу в межах від -5 до 2-го лага.

Кроскореляційні функції, отримані для трансмембранного потенціалу зародків, інкубованих у середовищах із кобальтом i цинком, характеризуються коливаннями, 3 максимальною амплі- тудою коефіцієнта кроскореляції $0,60(\mathrm{P}=0,05)$ у нульовому лазі (рис. 6в). Позитивні значення кроскореляційної функції перебувають у межах зміщень, що відповідають зсувам від -3 до 11-го. Достовірні значення кроскореляційної функції розміщені симетрично від максимального значення коефіцієнта кроскореляції у лагах від -2 до 2-го.

Для трансмембранного потенціалу, виміряного на зародках в’юна за інкубації в середовищах олова та цинку, розрахована кроскореляційна функція, достовірні значення якої перебувають у межах від 1 до 5-го лага (рис. 6в). Візуально крива характеризується коливанням, яке припадає на від'ємне значення зсуву. Максимальна амплітуда коливання кроскореляційної функції припадає на зсув у 30 хв (лаг 3$)$ і становить $0,66(\mathrm{P}=0,05)$.
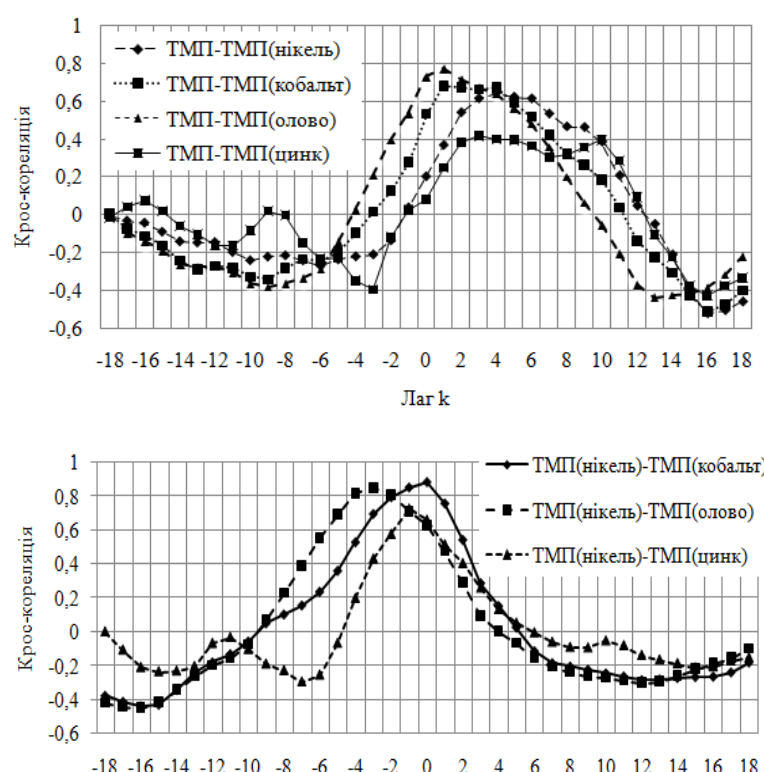

$\sigma$ Лark

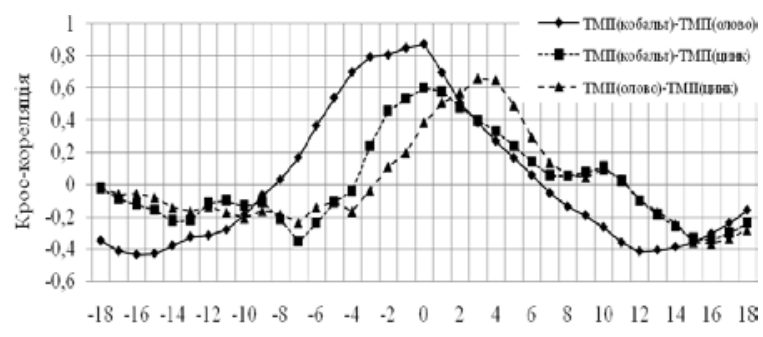

Лаг

Рис. 6. Крос-корелограми часових рядів трансмембранного потенціалу зародкових клітин, інкубованих за різного складу середовища: ТМП - трансмембранний потенціал зародків в'юна, інкубованих у розчині Гольтфретера, ТМП (нікель) трансмембранний потенціал зародків в'юна, інкубованих у розчині, що містив $10^{-5} \mathrm{M}$ нікелю, ТМП (кобальт) - трансмембранний потенціал зародків в'юна, інкубованих у розчині, що містив $10^{-4}$ М кобальту, ТМП (олово) - трансмембранний потенціал зародків в'юна, інкубованих у розчині, що містив $10^{-4}$ М олова, ТМП (цинк) - трансмембранний потенціал зародків в’юна, інкубованих у розчині, що містив $10^{-5} \mathrm{M}$ цинку

Із метою візуального зображення сили взаємодії між двома сигналами трансмембранного потенціалу зародкової клітини побудовано чотири кореляційні плеяди для часових зсувів, рівні 180 , 240, 300 та 360 хв. Загальний вигляд кореляційних плеяд показано як центри, об'єднані стрілками, які вказують на силу та напрям кореляційного зв'язку (рис. 7). Для цього попарно розглядали всі можливі шляхи взаємодій між параметрами, що описують генерацію трансмембранного потенціалу та регуляторних чинників на досліджуваному часовому проміжку, та позначали числами 1-5. Відстані між цими символами пропорційні значенням коефіцієн- 
тів кроскореляцій для певного моменту часового зсуву, де сила та напрямок кроскореляціної функції мають конкретне значення.

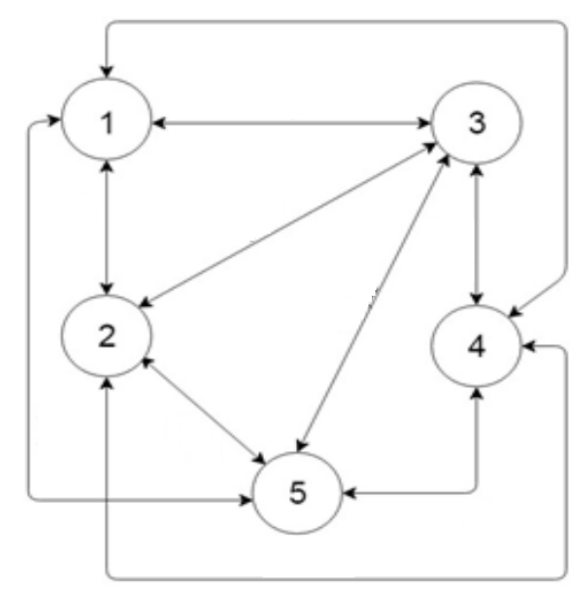

Рис. 7. Кореляційна плеяда: 1 - трансмембранний потенціал зародків в’юна, інкубованих у розчині Гольтфретера,

2 - трансмембранний потенціал зародків в'юна, інкубованих у розчині, що містив $10^{-5} \mathrm{M}$ нікелю, 3-трансмембранний потенціал зародків в'юна, інкубованих у розчині, що містив $10^{-4}$ М кобальту,

4-трансмембранний потенціал зародків в’юна, інкубованих у розчині, що містив $10^{-4}$ М олова, 5- трансмембранний потенціал зародків в'юна, інкубованих у розчині, що містив $10^{-5}$ М цинку, стрілками позначено зв’язок між параметрами

\section{Обговорення}

Численні літературні дані вказують, що іони важких металів здатні викликати порушення ембріонального розвитку у різних видах організмів, наприклад, безхребетних (Sisman, 2011; Gallo et al., 2016; Gallo, 2018), риб (Blewett et al., 2016; Blewett \& Leonard, 2017), чи молюсків (Ringwood et al., 2010). Наслідками негативного впливу на метаболічні процеси в ембріогенезі, зумовлені іонами нікелю, кобальту, олова та цинку, стали сповільнення розвитку (Behra, 1993; Blewett \& Leonard, 2017), виникнення морфологічних та функціональних аномалій (Dineley et al., 2003; Hwang et al., 2012; Tualla \& Bitacura, 2016), або смерті зародка (Cavas, 2008; Cai et al., 2012; Kucukoglu et al., 2013).

Автокореляційний та кроскореляційний аналізи продемонстрували зміну періодів коливань трансмембранних потенціалів зародків, інкубованих у середовищах з іонами важких металів, які можна вважати регуляторними чинниками іон-транспортувальних систем плазматичної мембрани клітини.

Автокорелограма - симетрична функція, значення якої залежить від часових зсувів. Таким чином, у разі збільшення кількості лагів крива автокореляції прямує до нуля. Суттєвих великих значень автокореляційна функція набирає до певного критичного лага. Для зародкових клітин в'юна, інкубованих у середовищі Гольтфретера, він рівний 30 хв. Збільшення величини критичного лага для автокорелограм трансмембранних потенціалів зародків, інкубованих у середовищі з іонами важких металів, вказує на зростання періоду коливань. Показники збільшення періодів коливань, які проаналізовано з автокореляційних функцій трансмембранних потенціалів зародків, інкубованих із нікелем, кобальтом і оловом, збігаються 3 даними Boyko \& Sanagursky (2000) про вплив іонів важких металів на динаміку трансмембранного потенціалу у ранньому ембріональному розвитку.

Отримані результати кроскореляційного аналізу свідчать, що поширення флуктуацій кроскореляцій зі складною динамікою виникає за часових зсувів як у прямому, так і зворотному напрямі. Коливний ефект чітко видно лише за дії іонів цинку на зародкові об'єкти, хоча значення коефіцієнтів не виходять за межі довірчого інтервалу. Наявність тісного кроскореляційного зв'язку за малих значень часових зсувів вказує на те, що іони важких металів впливають на динамічні зміни трансмембранного потенціалу.

За наявності іонів нікелю та кобальту в середовищах інкубації бластомери в'юна, максимального достовірного значення кроскореляція набирала за нульового лага. Пояснення цього факту полягає в тому, що нікель порушує іонний обмін (Blewett \& Leonard, 2017). За дії нікелю на ембріони морських їжаків Strongylocentrotus purpuratus виявлено зниження концентрації калію та підвищення рівня натрію, що вказує на інгібування $\mathrm{Na}^{+}, \mathrm{K}^{+}$-АТРази (Tellis et al., 2014). Іони кобальту блокують $\mathrm{K}^{+}$-канали, $\mathrm{Na}^{+}$-канали та змінюють фізичний стан ліпідної фази плазматичної мембрани (Cai et al., 2012). Крім того, кобальт у концентрації $10^{-6} \mathrm{M}$ інгібує $\mathrm{Na}^{+}, \mathrm{K}^{+}$-AТРазну активність (Kaplia, 2016), що, тим самим, зумовлює деполяризацію мембрани.

Отримані результати кроскореляційного аналізу свідчать, що за наявності іонів олова в середовищі інкубації зародків, максимальних достовірних значень коефіцієнти кореляції набирають за незначних часових зсувів. Очевидно, такий ефект зумовлений впливом олова на потенціал-керовані іонні канали (Tomaszewski \& Busselberg, 2008), хоча це питання потребує подалышого вивчення.

У разі наявності іонів цинку в середовищі інкубації зародків максимальних достовірних значень коефіцієнти кроскореляцій набирали за незначних часових зсувів. Такий результат, можливо, $\epsilon$ наслідком впливу цинку на системи мембранної сигналізації (MacDonald, 2000), а також підтверджує той факт, що цинк та інші двовалентні катіони алостерично регулюють ліганд-керовані іонні канали або інгібують іонні канали (Zimmermann et al., 2012).

Коефіцієнти кроскореляції - малоінформативні показники за великих часових зсувів, оскільки їх значення не виходять за межі довірчих інтервалів, тобто губляться значення того чи іншого чинника на живу систему.

Оскільки розраховані кроскореляції належать до однієї системи, яка являє собою зародковий об'єкт, і відображають стан відповідних їй елементів у часі, вони можуть бути використані для побудови структурно-функціональних схем - кореляційних плеяд. У запропонованих схемах наявні зворотні зв'язки. Побудовані кореляційні плеяди використовуються у подальшому для моделювання структурними рівняннями. Отже, їх можна застосувати для якісного опису параметрів системи, a також їх будують для створення математичних моделей для кількісного дослідження.

\section{Висновки}

Наведено результати аналізу часових рядів трансмембранних потенціалів зародкових клітин, інкубованих за різного складу середовища. Отримані в межах дослідження результати підтверджують існування тісного взаємозв'язку між наявністю у середовищі інкубації зародкових клітини у ранньому ембріогенезі іонів нікелю, кобальту, олова та цинку на величину зареєстрованого трансмембранного потенціалу. Період коливань трансмембранного потенціалу відмінний від норми за дії регуляторних чинників. Значення цих величин більші порівняно з такими для норми, що, ймовірно, викликано однаковими механізмами регулювання трансмембранного потенціалу. Отримані результати мають прикладне значення для подалыших досліджень взаємодій різних параметрів метаболізму у складних системах і дозволяють застосувати математичні підходи для прогнозування послідовності їх взаємодій.

\section{References}

Abdelalim, E. M. (2013). Molecular mechanisms controlling the cell cycle in embryonic stem cells. Stem Cell Reviews and Reports, 9(6), 764-773.

Barghouth, P. G., Thiruvalluvan, M., \& Oviedo, N. J. (2015). Bioelectrical regulation of cell cycle and the planarian model system. Biochimica et Biophysica Acta, 1848(10), 2629-2637.

Behra, R. (1993). In vitro effects of cadmium, zinc and lead on calmodulin-dependent actions in Oncorhynchus mykiss, Mytilus sp., and Chlamydomonas reinhardtii. Archives of Environmental Contamination and Toxicology, 24(1), 21-27. 
Blackiston, D. J., McLaughlin, K. A., \& Levin, M. (2009). Bioelectric controls of cell proliferation: Ion channels, membrane voltage and the cell cycle. Cell Cycle, 8(21), 3519-3528.

Blewett, T. A., \& Leonard, E. M. (2017). Mechanisms of nickel toxicity to fish and invertebrates in marine and estuarine waters. Environmental Pollution, 223, 311-322.

Blewett, T. A., Smith, D. S., Wood, C. M., \& Glover, C. N. (2016). Mechanisms of nickel toxicity in the highly sensitive embryos of the sea urchin Evechinus chloroticus, and the modifying effects of natural organic matter. Environmental Science and Technology, 50(3), 1595-1603.

Boiko, N., \& Sanagursky, D. (2000). Dynamika transmembrannoho potentsialu zarodkiv v’yuna v umovakh vplyvu ioniv vazhkykh metaliv [Dynamics of transmembrane potential of germ breeding in conditions of influence of heavy metal ions]. Visnyk of Lviv University. Series Biological, 25, 3-7 (in Ukrainian).

Box, G. E. P., Jenkins, G. M., \& Reinsel, G. C. (2013). Time series analysis: Forecasting and control. John Wiley and Sons, Inc.

Cai, G., Zhu, J., Shen, C., Cui, Y., Du, J., \& Chen, X. (2012). The effects of cobalt on the development, oxidative stress, and apoptosis in zebrafish embryos. Biological Trace Element Research, 150(1), 200-207.

Cavas, T. (2008). In vivo genotoxicity of mercury chloride and lead acetate: Micronucleus test on acridine orange stained fish cells. Food and Chemical Toxicology, 46, 352-358.

Dineley, K. E., Votyakova, T. V., \& Reynolds, I. J. (2003). Zinc inhibition of cellular energy production: Implications for mitochondria and neurodegeneration. Journal of Neurochemistry, 85, 563-570.

Fabricio Neta, A. B., do Nascimento, C. W. A., Biondi, C. M., van Straaten, P., \& Bittar, S. M. B. (2018). Natural concentrations and reference values for trace elements in soils of a tropical volcanic archipelago. Environmental Geochemistry and Health, 40(1), 163-173.

Gallo, A. (2018). Toxicity of marine pollutants on the ascidian oocyte physiology: An electrophysiological approach. Zygote, 26(1), 14-23.

Gallo, A., Boni, R., Buttino, I., \& Tosti, E. (2016). Spermiotoxicity of nickel nanoparticles in the marine invertebrate Ciona intestinalis (ascidians). Nanotoxicology, 10(8), 1096-1104.

Galyk, G. V. (2017). Vplyv ioniv vazhkykh metaliv na metabolizm zarodkovykh klityn [The impact of heavy metals on the metabolism of germ cells]. Experimental and Clinical Physiology and Biochemistry, 1, 58-65 (in Ukrainian).

Gevorgyan, G. A., Mamyan, A. S., Hambaryan, L. R., Khudaverdyan, S. K., \& Vaseashta, A. (2016). Environmental risk assessment of heavy metal pollution in Armenian river ecosystems: Case study of Lake Sevan and Debed River catchment basins. Polish Journal of Environmental Studies, 25(6), 2387-2399.

Goyda, O. A. (1993). Biofizicheskiye aspekty rannego ontogeneza zhivotnykh [Biophysical aspects of early ontogenesis of animals]. Naukova Dumka, Kyiv (in Russian).

Hwang, U. K., Park, J. S., Kwon, J. N., Heo, S., Oshima, Y., \& Kang, H. S. (2012). Effect of nickel on embryo development and expression of metallothionein gene in the sea urchin (Hemicentrotus pulcherrimus). Journal Faculty of Agriculture Kyushu University, 57(1), 145-149.
Ivashkiv, L., Hraduk, M., \& Sanagursky, D. (2001). Analiz kros-korelyatsiy u chasovykh zminakh fizyko-khimichnykh pokaznykiv rozvytku zarodkiv v'yuna [Analysis of cross-correlations in temporary changes of physical and chemical parameters of loach germs' development]. Visnyk of Lviv University. Series Biological, 27, 3-11.

Jezierska, B., Ługowska, K., \& Witeska, M. (2008). The effects of heavy metals on embryonic development of fish (a review). Fish Physiology and Biochemistry, 35(4), 625-640.

Jitar, O., Teodosiu, C., Oros, A., Plavan, G., \& Nicoara, M. (2015). Bioaccumulation of heavy metals in marine organisms from the Romanian sector of the Black Sea. New Biotechnology, 32(3), 369-378.

Kaplia, A. A. (2016). The influence of heavy metal ions, spermine and sodium nitroprusside on ATP-hydrolases of cell membranes of rat colon smooth muscle. Ukrainian Biochemical Journal, 88(4), 20-28.

Kucukoglu, M., Binokay, U. S., \& Boga Pekmezekmer, A. (2013). The effects of zinc chloride during early development in zebrafish (Brachydanio rerio). Turkish Journal of Biology, 37, 158-164.

MacDonald, R. S. (2000). The role of zinc in growth and cell proliferation. The Journal of Nutrition, 130(5), 1500S-1508S.

Marzan, L. W., Hossain, M., Mina, S. A., Akter, Y., \& Masudul Azad Chowdhury, A. M. (2017). Isolation and biochemical characterization of heavy-metal resistant bacteria from tannery effluent in Chittagong city, Bangladesh: Bioremediation viewpoint. The Egyptian Joumal of Aquatic Research, 43(1), 65-74.

Reversade, B., \& De Robertis, E. M. (2005). Regulation of ADMP and BMP2/4/7 at opposite embryonic poles generates a self-regulating morphogenetic field. Cell, 123, 1147-1160.

Ringwood, A. H., McCarthy, M., Bates, T. C., \& Carroll, D. L. (2010). The effects of silver nanoparticles on oyster embryos. Marine Environmental Research, 69, 49-51.

Sanagursky, D. I., \& Goyda, E. A. (1980). Opisaniye biologicheskikh struktur s pozitsiy ikh organizatsii [Description of biological structures from the perspective of their organization]. Bionics Issues, 24, 100-105 (in Russian).

Sisman, T. (2011). Early life stage and genetic toxicity of stannous chloride on zebrafish embryos and adults: toxic effects of tin on zebrafish. Environmental Toxicology, 26(3), 240-249.

Tellis, M. S., Lauer, M. M., Nadella, S., Bianchini, A., \& Wood, C. M. (2014). The effects of copper and nickel on the embryonic life stages of the purple sea urchin (Strongylocentrotus purpuratus). Archives of Environmental Contamination and Toxicology, 67(3), 453-464.

Tomaszewski, A., \& Busselberg, D. (2008). $\mathrm{SnCl}_{2}$ reduces voltage-activated calcium channel currents of dorsal root ganglion neurons of rats. NeuroToxicology, 29, 958-963.

Tualla, I. P. B., \& Bitacura, G. (2016). Effects of cadmium and zinc on the gamete viability, fertilization, and embryonic development of Tripneustes gratilla (Linnaeus). Scientifica (Cairo), 8175213.

Zimmermann, I., Marabelli, A., Bertozzi, C., Sivilotti, L. G., \& Dutzler, R. (2012). Inhibition of the prokaryotic pentameric ligand-gated ion channel ELIC by divalent cations. PLoS Biology, 10(11), e1001429. 